NOT I C E

THIS DOCUMENT HAS BEEN REPRODUCED FROM MICROFICHE. ALTHOUGH IT IS RECOGNIZED THAT CERTAIN PORTIONS ARE ILLEGIBLE, IT IS BEING RELEASED

IN THE INTEREST OF MAKING AVAILABLE AS MUCH INFORMATION AS POSSIBLE 
(NASA-TH-83890) AN INVENTORY OF

UNDI SCOVERED CANADIAN MINERAL RESOURCES

$N 82-21688$

(NASA) 40 p HC A03/HF A01

CSCL OBG

$63 / 43 \quad \begin{aligned} & \text { Unclas } \\ & 18794\end{aligned}$

NMSA

\section{rechnical Memorandum 83890}

AN INVENTORY OF

UNDISCOVERED CANADIAN

MINERAL RESOURCES

M. L. Labovitz and J. C. Griffiths

JANUARY 1982

National Aeronautics and

Space Administration

Goddard Space Flight Center

Greenbelt, Maryland 20771

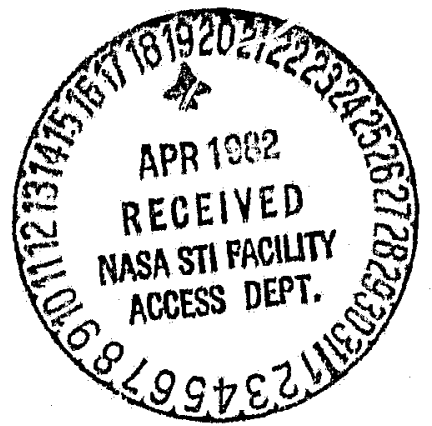




\title{
AN INVENTORY OF UNDISCOVERED CANADIAN MINERAL RESOURCES
}

\author{
${ }^{1}$ M. L. Labovitz \\ and \\ 2J. C. Griffiths
}

January 1982

\footnotetext{
${ }^{1}$ Phy/sical Scientist, Geophysics Branch, National Aeronautics and Space Administration, Greenbelt, MD 20771.

${ }^{2}$ Professor Emeritus of Petrography, Department of Geosciences, The Pennsylvania State University, University Park, PA 16802.
} 


\title{
PRECEDING PAGE BLANK NOT FILMED
}

\section{AN INVENTORY OF UNDISCOVERED CANADIAN MINERAL RESOURCES}

\begin{abstract}
Unit regional value (URV) and unit regional weight (URW) are area standardized measures of the expected value and quantity, respectively, of the mineral resources of a region. Estimation and n)anipulation of the URV statistic is the basis of approach to mineral resource evaluation. Estimates of the kind and value of exploitable mingral resources yet to be discovered in the province; of Canada are used as an illustration of the procedure.
\end{abstract}

The URV statistic is set within a previously developed model wherein geology, as measured by point counting geologic maps, is related to the historical record of mineral resource production of well-developed regions of the world, such as the 50 states of the U.S.A.; these may be considered the training set. The Canadian provinces are related to this training set using geological information obtained in the same way from geologic maps of the provinces. The desired predictions of yet to be discovered mineral resources in the Canadian provinces arise as a consequence. The implicit assumption is that regions of similar geology, if equally well developed, will produce similar weights and values of mineral resources.

An example of an inventory of undiscovered, explorable mineral commodities and their probatility of oncurrence is given for the province of Manitoba. The value of undiscovered mineral commodities in the Yukon, Labrador, the Island of Newfoundland, Saskatchewan and Manitoba is conservatively estimated at greater than 15,000 U.S. 1967 dollars per $\mathrm{km}^{2}$.

The URV approach is an objective, reproducible method of mineral resource assessment. Use of the technique stresses the need to operationalize or quantify geology and mineral resource variables, so that algebraic manipulation and formal hypothesis testing can be performed. 


\section{- AN INVENTORY OF IJNDISCOVERED CANADIAN MINERAL RESOURCES}

\section{INTR,ODUCTION AND OBJECTIVE}

In 1967, J. C. Griffiths (1967a) proposed that the U.S. be explored for nonrenewable mineral resources by drilling the country on a 20 mile square grid. This proposal is mentioned because two of the fertitres underlying the scheme have a direct bearing on the research presented below. First, one of the objectives of grid drilling is to obtain an inventory of nonrenewable mineral resources. Second, the economic success of the grid drilling proposal is based upon a multi-commodity search, that is all targets which are economically exploitable are considered desirable and are searched for at the same time. Continuing his research in exploration philosophy, Griffiths (1969), examined the rationale used by an explorationist to choose an area to explore. Griffiths reasoned that an input to the explorationist's decision process might be the value of the mineral resources in the area chosen for exploration. The Unit regional value (URV) approach to mineral resource evaluation, as this research has become known, has the following as its basis. ${ }^{\perp}$ An estimate of the value of mineral resources to be found in large underdeveloped regions of the world is obtained by examining mineral resource production in well developed regions.? Thus if mineral resources of a region are considered equivalent to its past production the estimate may be obtained by cumulating the production, both weight and value, over the history of production. Since it is expected that larger regions will produce more resources, the effects in variation of region size is removed by prorating (dividing) the aggregated (summesi) production by the area of the region. The resulting estimates are called the unit region value and unit regional weight. Application of the unit regional value (URV), leads to a first unconditional, albeit, because not even well developed regions are exnausted,

\footnotetext{
${ }^{1}$ A more complete discussion of the Unit Regional Value philosophy as weli as a summary of results from other studies can be found in Griffiths, 1978 and Missan, et al., 1978.

${ }^{2}$ A region is a sampling unit, politically defined, and to a first approximation is independent of the distribution of resources. A region is therefore a large political unit considered a random sample of the earth's crust. From past analysis (Griffiths, 1969; Labovitz, 1976), it was noted that political units is small as the counties of Kansas and California (approximately $5170 \mathrm{~km}^{2}$ ) could be considered random samples. Therefore a region is equivalent to a state in the U.S. or a province in Canada.
} 
conservative estimate of the value of mineral resource production to be realized from large under. developed regions. Calculating the URV for a large number of moderately developed to well developed regions will yield a frequency distribution and thus a more precise estimate of the ex* pected value of production. Then, if the training regions follow a tractable frequency function, the moments (the mean, variance etc) of this distribution can be used to estimate confidence limits about the expected value. This information can be used by an explorationist to set $\mathrm{tr}_{r}$ confidence limits on the value of mineral production to be realized from an area of a given size. Using these limits, the explorationist can decide how much to spend for exploration and develoyment.

In this paper we present the unit regional value approach in the context of a case study, with Canada as the study location. First we derive URV estimates for the Canadian provinces and territories (provinces will henceforth include provinces and territories) and achieve a general sense of their meaning by comparison with the states of the U.S. We also show how this comparison can evolve into predictive statements.

These predictions rest upon the assumption that the states of the U.S. and the provinces of Canada are random samples of the earth's crust. Such predictions therefore may be refined by subdividing locations into geologically more similar groups or subpopulations; the implicit assumption is that regions of similar geology if equally well developed will produce similar mineral resources. So in later sections of the paper we propose a model which helps to create these subpopulations, these subpopulations are then used to examine relationships between geology and mineral resources. From these relationships we predict the number, kinds, and value of mineral commodities yet to be discovered in the provinces of Canada.

\section{THE URV OF THE STUDY LOCATIONS}

The URV's of the states of the United States are displayed in Figure 1. This figure represents the aggregation of the constant-dollar value (conversion to 1967 dollars via the wholesale price index) of annual mineral resource production for the period 1905 to 1973 . For each state the 


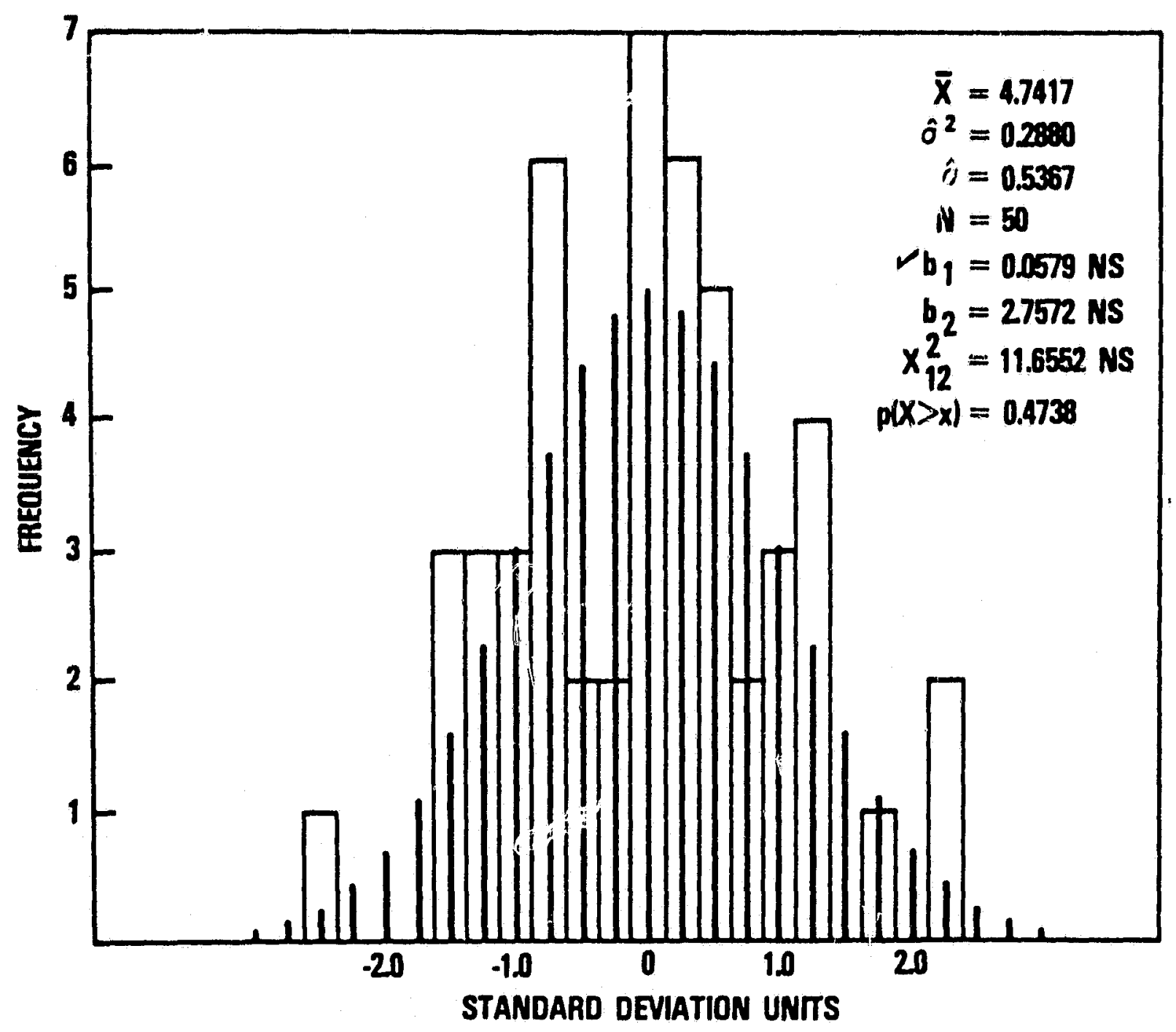

Figure 1. Comparison of observed frequency histogram of $\log _{10}$ URV (in 1967 U.S. dollars $/ \mathrm{km}^{2}$ of the U.S. states with the expected normal distribution possessing the same mean and variance. The statistics $\sqrt{ } b_{1}, b_{2}$ and $X_{12}^{2}$ are used in tests of the skewness, kurtosis and goodness of fit, respectively. NS means that the statistic is not significantly different from the value for a normal distribution. 
aggregated value of resource production has been divided by its area (in square kilometers) and is then expressed in logarithms to the base 10. The value for the states of the U.S. is log normally distributed with a mean of $4.7417(\$ 55,170)$ per square kilometer. There are too few Canadian locations (12) to fit to a frequency distribution, but the logarithms of the URV's of the Canadian provinees (Figure 2) have a mean of 4.0420 ( $\$ 11,015)$; the variances of the two samples 0.2880 and 0.3548 respectively are not significantly different from one another using Bartlett's test for homogeneity of variance (Bartlett, 1954), $B=0.2009$ compared to an $\alpha=0.05$ critical value of 3.841. Pooling the variances and testing for equality of the means, we find that the provinces of Canada have a significantly lower URV than the states of the U.S, $\left(t^{*}=9.891\right.$ compared to an $\alpha=0.05$ critical value of 2.000 based on student's $t$ distribution with 60 degrees of freedom). Comparing in greater detail, the states of the U.S. with the provinces of Canada (Figure 2), it can be seen that only one province, Nova Scotia, is above the mean of the states of the U.S. While the URV's of three provinces - Alberta, Ontario and New Brunswick - are within one standard deviation below the mean, three other Canadian locations - Prince Edward Island, Yukon and Northwest Territories are more than two standard deviations below the mean of the U.S. states. Thus the indications are that the provinces of Canada are underdeveloped in mineral resources vis-ì-vis the states of the U.S. While this statement would be considered almost intuitive to a great many economic geologists and mineral economists, it is based upon a measure that has not existed previously. This measure provides a quantitative, reproducible and, hence, an objective appraisal of mineral resource production which could be used in predictions and decision making. For example, one may use the stated differences in URV to note that if the URV of the Northwest Territories is raised just to the mean of the U.S. states, an additional $\$ 160 \times 10^{9}$ (1967 dollars) would be realized. When the overall totals are subdivided into totals for each resource sector, such as construction materials, fuels and nonmetals, and analyze results indicate the same pattern of relative undpordeveiopment of the Canadian provinces (Labovitz, 1978). 


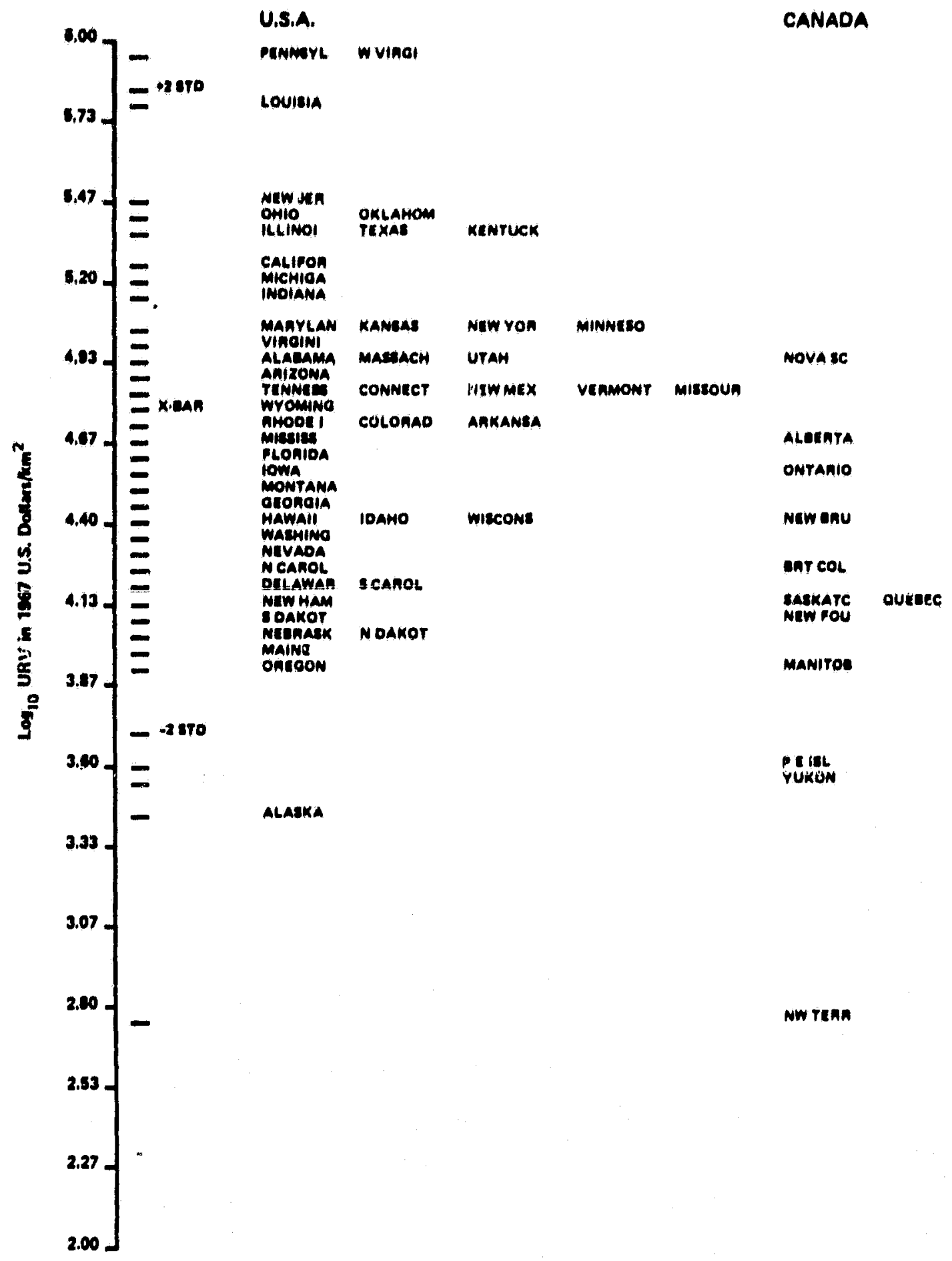

Figure 2. Comparison of total production of mineral resources in U.S. states and Canadian provinces. The mean, XBAR, and standard deviation are estimated from the U.S. states. 


\section{MINERAL RESOURCE MODEL}

The above results are not explicitly conditioned upon any other variables. The remainder of this paper will set forth and apply a model which incorporates other types of information. The data cube (Figure 3) is used in this paper as the operational form of the inputs and outputs of the mineral resource model. It has three dimensions. One of these dimensions, called the characterist!cs of a region, consists of socio-economic, mineral commodity and geologit variables. The second dimension, location, is composed of those regions of the world under study, The third dimension time - is composed of the periods when observation of the characteristics are made on the locations. Thus each cell of the data cube ${ }^{3}$ represents the observation of a characteristic at a given location for a specified time. The interrelations of the characteristics given in the data cube are expressed conceptually and in their fullest generality in the model displayed in Figure 4. The model used to represent the mineral resource system is an input - output or "black-box" model (Ashby, 1971). The model has four elements - input, output, processor (black-box) and feedback. One injut to the system consists of a group of socioeconomic variables represented in Figure 4 by the term com* mitment; this includes for example, how much money h'e ars willing to spend, how many geo* scientists are to be committed to the project, how much land will be available for exploration ete. The other input to the model is a group of geologic factors. For a specific study area these would include lithological, tectonic, physiographic or metallogenic province and geophysical characteristics. The outputs of the system are functions of the production of mineral resources - the number and kinds of mineral resources produced, their value and quantity. The inputs are related to outputs through the processor or black-box. The processor is an aggregation of many phases of the mineral resource system such as exploration, development, exploitation, transportation, etc. Operationally, the relationship between the input and output is described mathematically or statistically through a variety of modeling techniques. The fourth element - feedback - is the means by which the

\footnotetext{
${ }^{3}$ The use of the data cube in mineral resource analysis is covered more fully in Menzie et, al., 1977 and Labovitz et. al., 1977.
} 


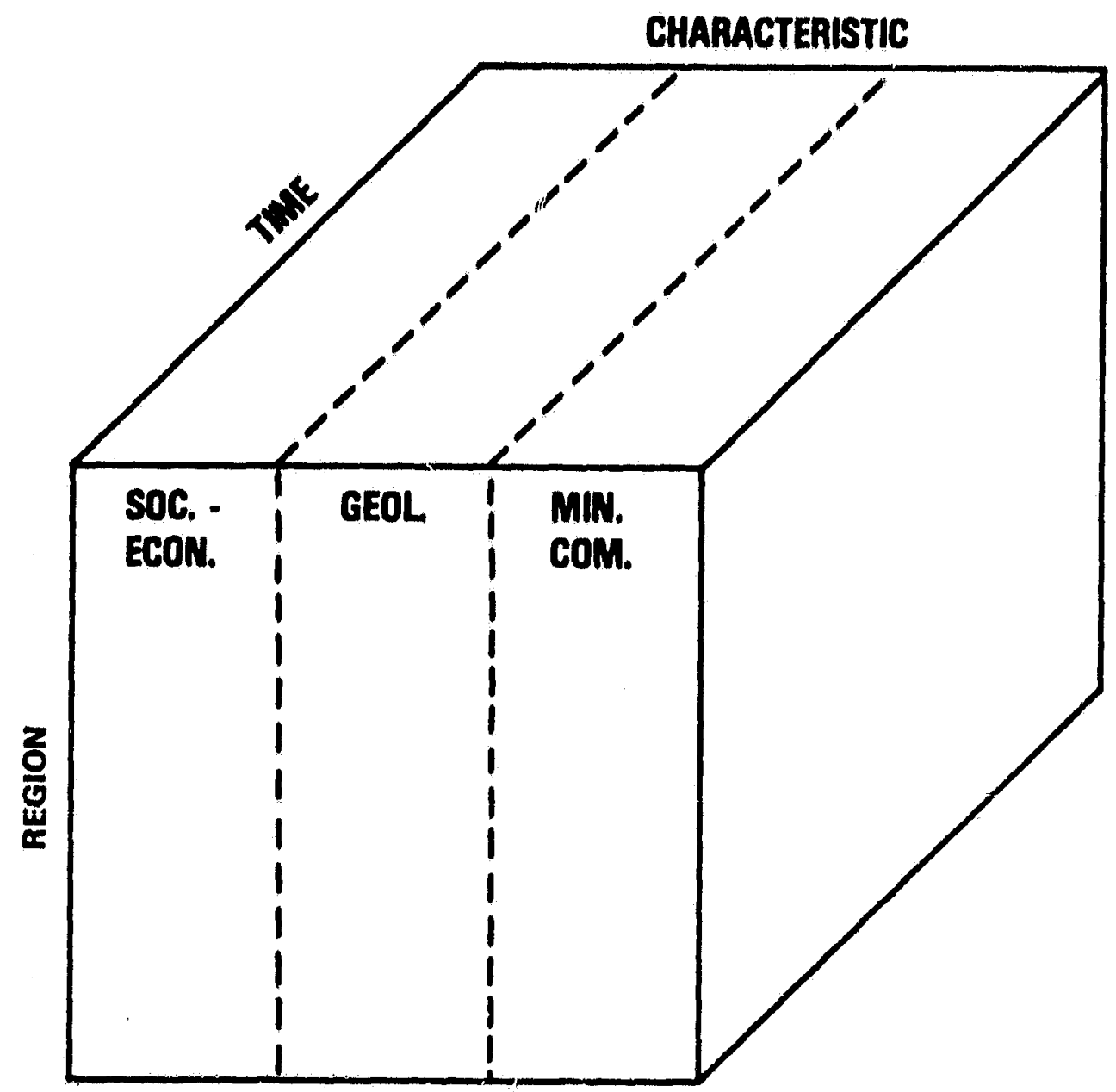

Figure 3. The data cube exnibitirig the three dimensions of characteristics, time and regions.

output acts upon the input and processor. For example, the quantity of proved petroleum reserves infuences the resources allocated to the search for petroleum. It is often in the feedback that the system's evolution or dynamics are displayed. Figure 4, as previously noted, presents the model in its fullest generality. We now simplify and operationalize the model for the present application. The input, processor and cutput portions of the mineral resource model as used in this paper are examined below. 


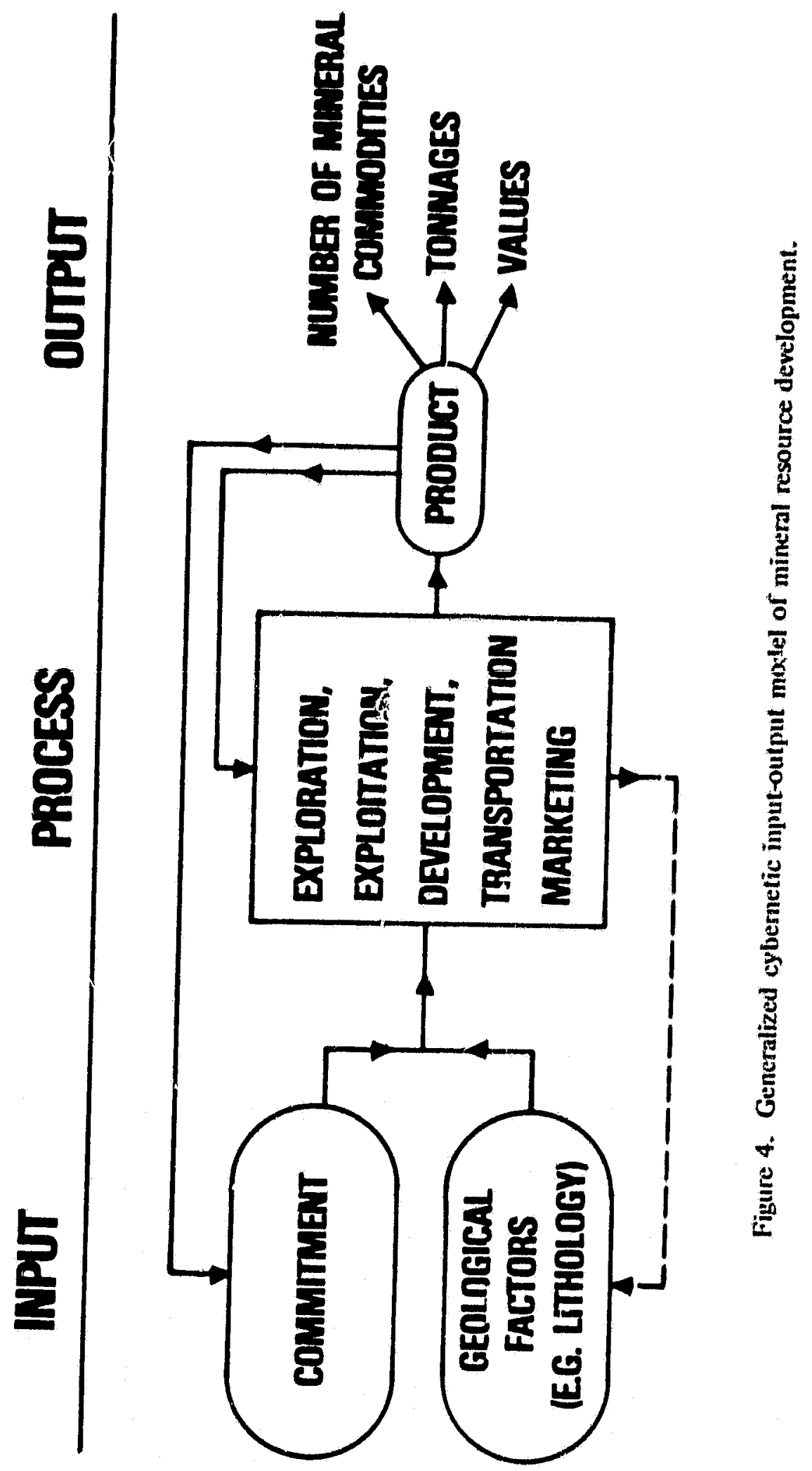




\section{The Output}

The outputs of the system are functions of the mineral resource production: thus, to be able to relate production from different locts:ins the mineral resources must be expressed in equivalent form and so a standard set of mineral resources called file 2 was created (Labovitz ef al., 1977) along with a set of mappings translating local names for the resources (file 1) to the file 2 commodities. Table I presents the file 2 names and numerical codes. There are 74 "recognizable" mineral resource commodities divided into 5 resource sectors - construction materials, fuels, metals, nonmetals and precious materials - plus 12 "accounting" codes or resource sector subtotuls. Table 1 also displays the file 2 commoditles discovered to date in Canada. Here, the terms discovery or occurrence (the latter is used later) of a mineral commodity means that the commodity has existed or exists in economically exploitable quantities as defined by the records of historical production.

\section{The Input}

The difficulty in examining lithology as an input to the system, is in comparing a liost of local names. This once again necessitated the development of a standard and operationalized geo. logie classification. The "time-petrographic" classification, (Menzie, 1977) Figure 5, is composed of two dimensions - age and lithology which are combined to form 70 classes.

The sedimentary classification is based on Krynine (1948) as modified by Griffiths (1974) and Menzie (1977). This classification of the detrital rocks is used for several reasons. First, it has a tectonic basis that is using the "end-members" of Krynine (1948), the rocks can be related to the tectonic settings of their formation. Second, these detrital rock types have a quantitative or operational definition given by Griffiths (1967b, 1977). The igneous rock classification is based on criteria from Hurlburt (1956) as modified by Menzie (1977). The meiamorphic rocks, at the

\footnotetext{
${ }^{4}$ Sources for Canadian mineral commodity data are given after References.

${ }^{5}$ Geologic maps used in point counts are given after References.
} 


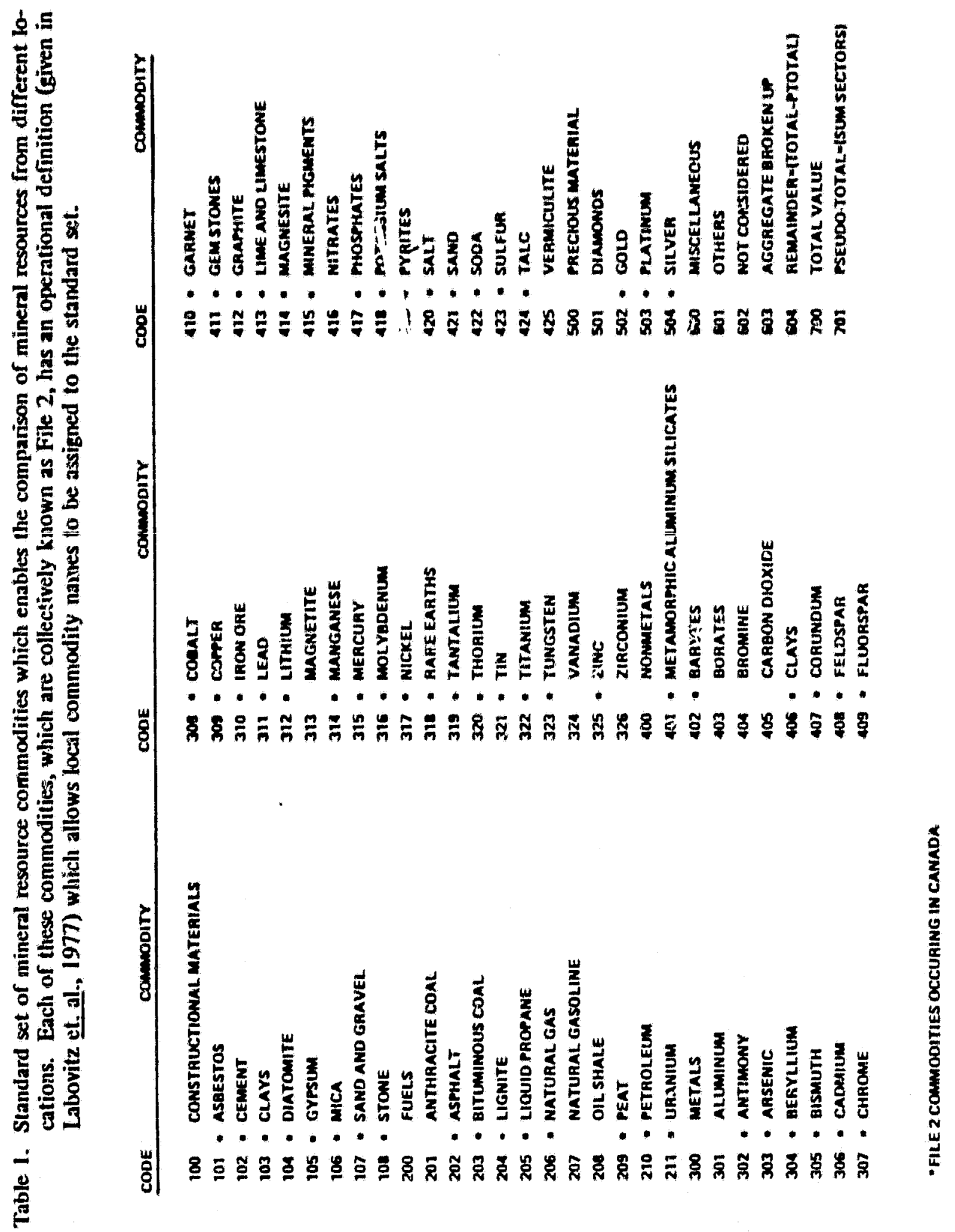




\section{TIME}

ROCK TYPE

OTHERS

REGIONAL METAMORPHIC ROCKS

ULTRABASIC EXTRUSIVE ROCKS

ULTRABASIC INTRUSIVE ROCKS

BASIC EXTRUSIVE ROCKS

BASIC INTRUSIVE ROCKS

ACID EXTRUSIVE ROCKS

ACID INTRUSIVE ROCKS

EVAPORTE ROCKS

CARBONATE ROCKS

HIGH RANK GRAYWACKE

LOW RANK GRAYWACKE
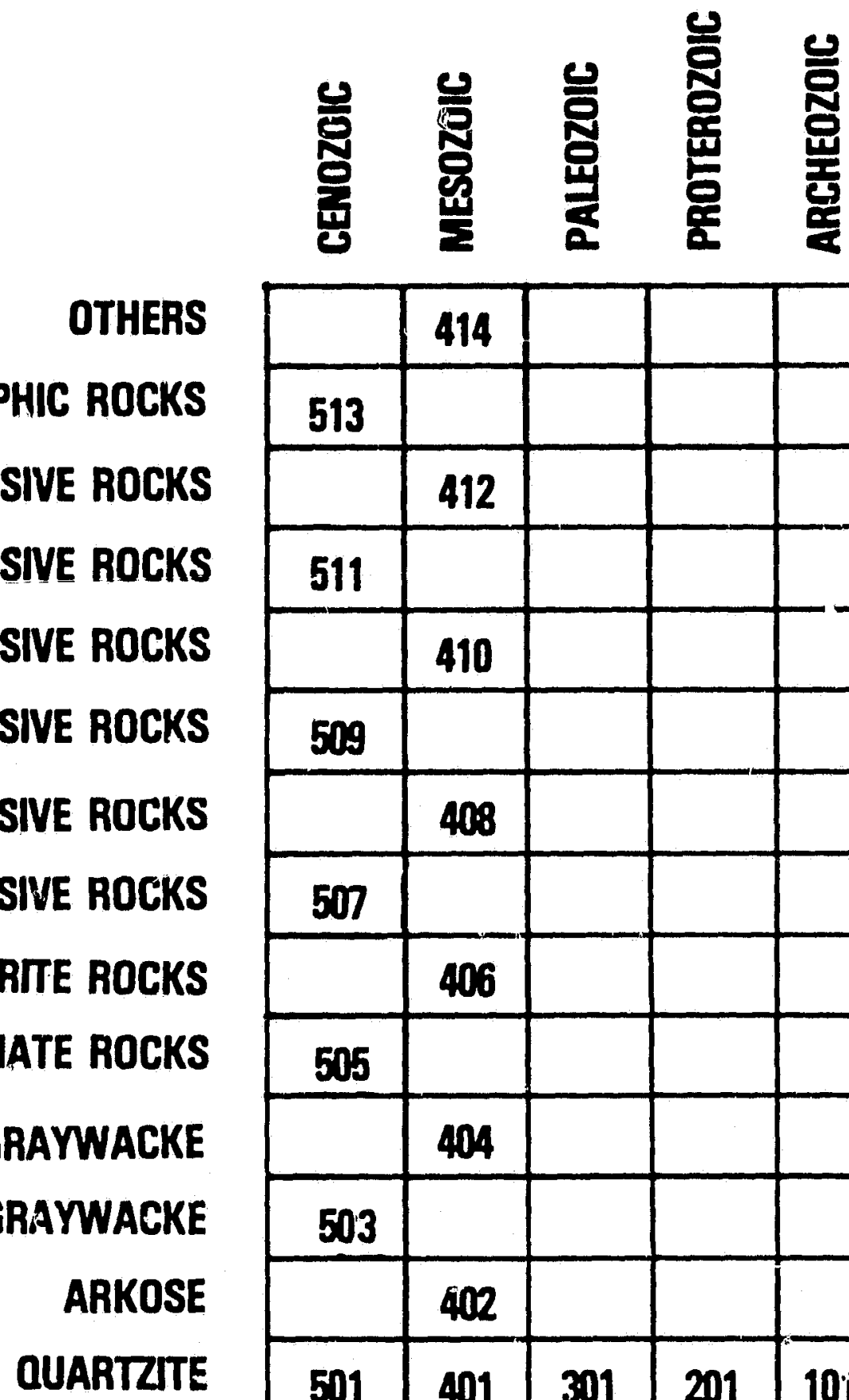

\begin{tabular}{|l|l|l|l|l|}
\hline & 414 & & & \\
\hline 513 & & & & \\
\hline & 412 & & & \\
\hline 511 & & & & \\
\hline & 410 & & & \\
\hline 509 & & & & \\
\hline & 408 & & & \\
\hline 507 & & & & \\
\hline & 406 & & & \\
\hline 505 & & & & \\
\hline & 404 & & & \\
\hline 503 & & & & \\
\hline & 402 & & & \\
\hline 501 & 401 & 301 & 201 & 101 \\
\hline
\end{tabular}

Figure 5. "Time Petrographic" classification (from Menzie, 1977; modified by Watson, 1977). 
scale of the maps used, are limited to slates, phyllites, schists, gneisses and marbles. These ate all assigned to the class called Regional Metamorphic Rocks. A 14th petrographic class called "others" is available for rocks which do not belong to the first 13 classes.

Geologic time is, in this scheme, grouped into five eras. The three eras composing the Phanerozoic - the Paleozoic, Mesozoic and Cenozoic - are well defined. The Precambrian is divided into two eras - Arsheozoic and the Proterozoic. The relation between the subdivisions used in the "time-petrographic" classification is given in Figure 6 (modified after King, 1977, from Labovitz, 1978). Thus, rocks of Archean age are placed in the Archeozoic and rocks of Aphebian, Helikian, or Hadrynian Ages are considered to be in the Proterozoic. The description and use of the "time-petrographic" classification is given in greater detail in Griffiths (1978).

\begin{tabular}{|c|c|c|}
\hline $\begin{array}{l}\text { "TIME-PETROGRAPHIC" } \\
\text { CLASSIFICATION }\end{array}$ & $\begin{array}{c}\text { EVENT } \\
\text { (IN MILLIONS OF } \\
\text { YEARS) }\end{array}$ & $\begin{array}{c}\text { GEOLOGICAL } \\
\text { SUAVEY } \\
\text { OF } \\
\text { CANADA }\end{array}$ \\
\hline Palcozoic & & Cambrian \\
\hline \multirow{6}{*}{ Proterazole } & $\begin{array}{l}\text { Avalonien } \\
570-650 \mathrm{~m} . \mathrm{y}\end{array}$ & \multirow{2}{*}{ Hadrynian } \\
\hline & & \\
\hline & $\begin{array}{c}\text { Grenvillian } \\
900-1,100 \mathrm{~m}, \mathrm{v}\end{array}$ & \multirow{2}{*}{ Holikien } \\
\hline & $\begin{array}{c}\text { Elsonian } \\
1,300-1,400 \mathrm{~m}, \mathrm{y}\end{array}$ & \\
\hline & $\begin{array}{c}\begin{array}{c}\text { Hudsonian } \\
\text { (mponokean) }\end{array} \\
1,700-1,800 \mathrm{~m} . \mathrm{y} .\end{array}$ & \multirow{2}{*}{ Aphebian } \\
\hline & \multirow{2}{*}{$\begin{array}{c}\text { Kenoran } \\
(=\text { Algoman) } \\
2,500-2,700 \mathrm{~m} . \mathrm{y} .\end{array}$} & \\
\hline Archeozoic & & Archean \\
\hline
\end{tabular}

Figure 6. Relationship between subdivisions of Canadian Precambrian and "time-petrographic" classification (after King 1977, and Labovitz, 1978). 
Data forming the input were collected by placing a transparent square grid on the geologic map of the study area. The map symbol falling under the intersection is noted and a determination made as to which "time-petrographic" class the map symibol belonged (Griffiths of al., 1979b), For Canuda the objective was to observe the geology every 8 to 10 miles ( 12 to $16 \mathrm{~km}$ ) and so the size of the sampling grid was adjusted to conform with the map scale (see Table 2). The Northwest Territories is the only location in Canada for which the sampling interval is greater than the targeted value and this arises because there is no compilation map of NWT at a suitable scale (a scale no smaller than 1 to $1,500,000$ ). The point count of Canadian geology is composed of 37,475 observations (Labovitz, 1978).

\section{The Processor}

Figure 7 is an abstraction of the model given in Figure 4 and may be used to note the potential richness of the model, that is the number of potential configurations relating input to output variables. For instance, if the set of values that the 70 geologic variables and the 74 mineral commodities can take on consists of 0 or 1 (presence or absence), then there are $2^{70}$ possible geologic configurations and $2^{74}$ possible mineral resource commodity mixes; so the possible number of configurations that the system may take on is $2^{70 \cdot 2^{74}}$. Thus this model has the ability to represent a large number of system configurations even though based on presence - absence data.

The remainder of the paper will use these data to examine the relationship between the presence or absence of "time-petrographic" units and the presence or absence of mineral resources. The rationale for use of presence-absence data in this analysis is to try to see through the impact of economics upon the mineral resource system. This approach is suggested by previous research in which Labovitz (1976) and Menzie (1977) found that, while geology may set broad upper and lower bounds on the resource endowment of an area, the actual level of production is largely a function of non-geologic variables, including economic factors. Potentially then the presence-absence data and not the level of production will reflect more cleariy the relationship between geology and mineral resources. 


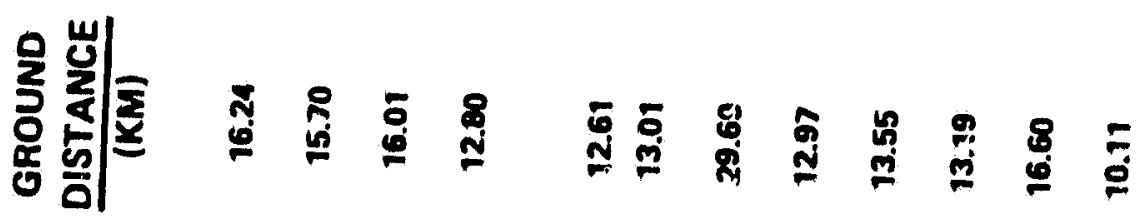

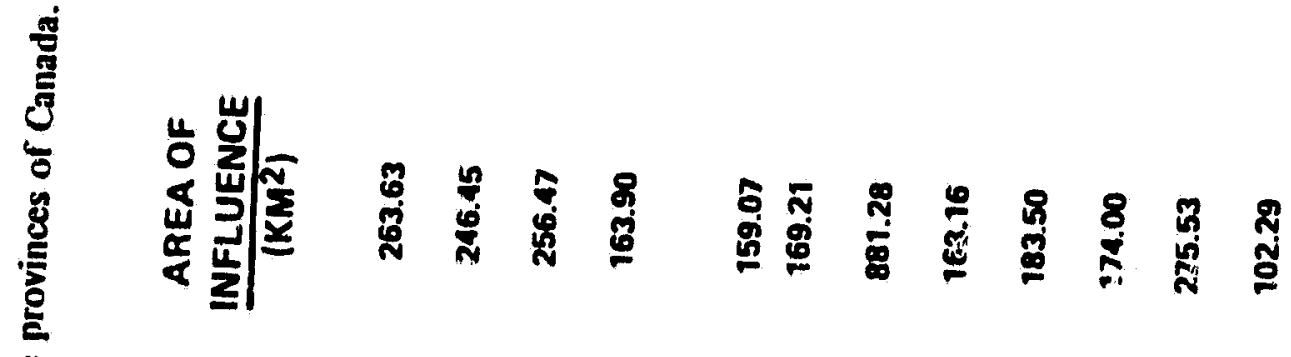

$\stackrel{2}{2}$

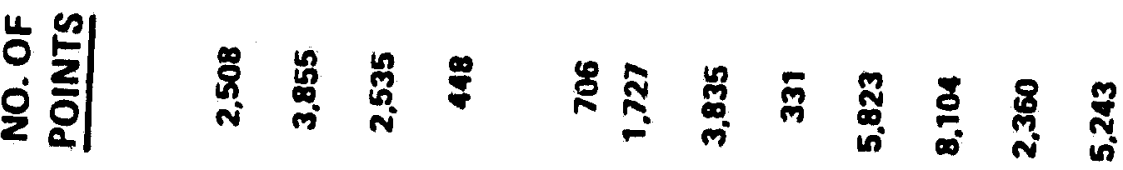

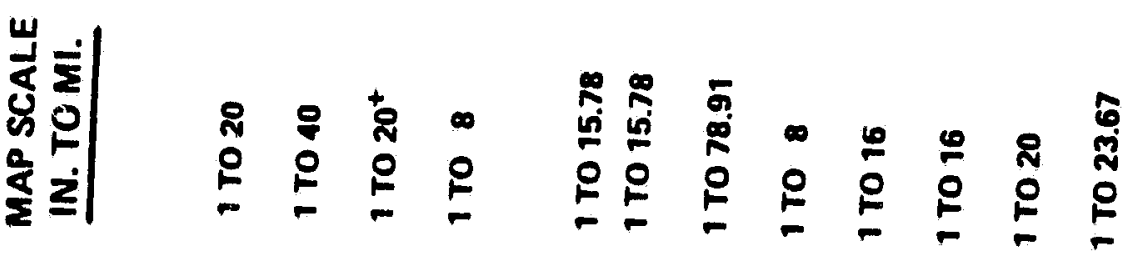

产

畩

吾

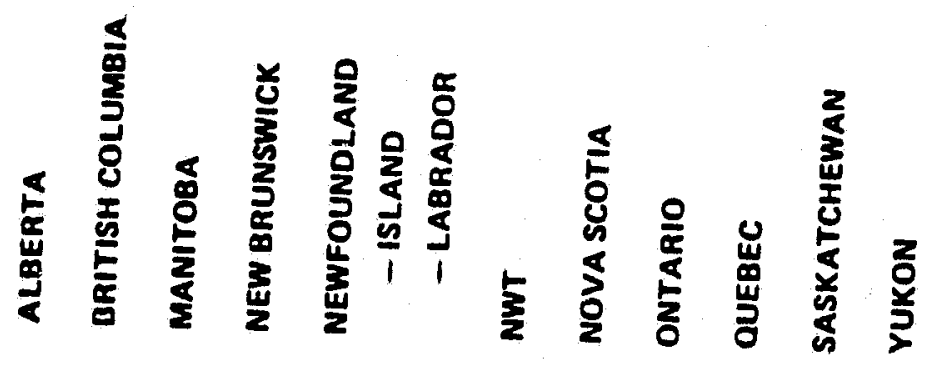




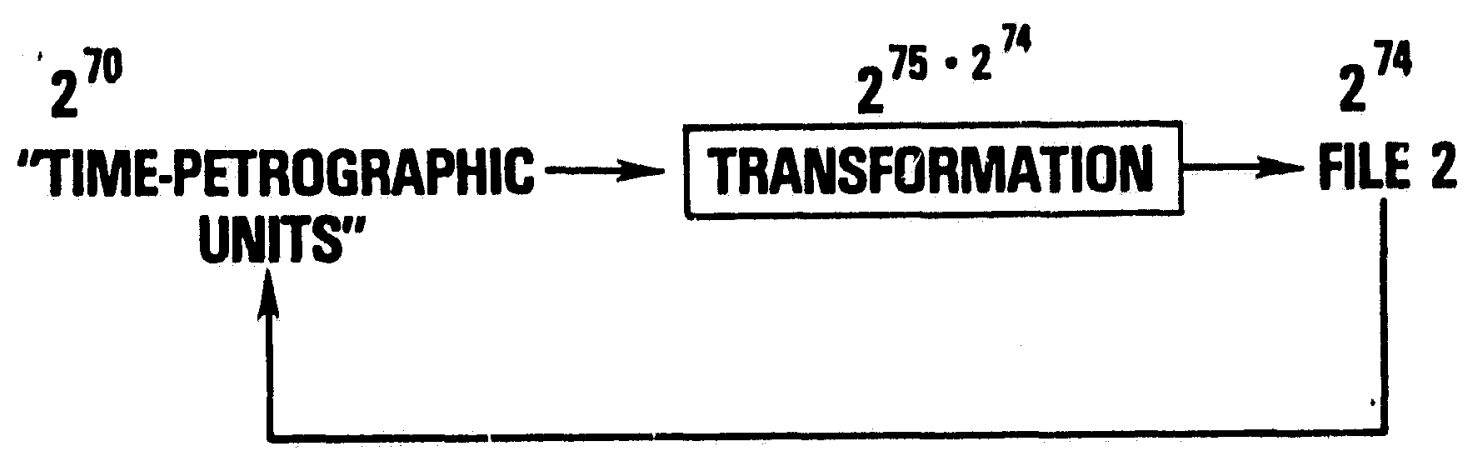

Figure 7. Input-output model of Figure 4 displaying relationships between varieties of timepetrographic inputs and mineral resource outputs.

\section{OVERVIEW OF ANALYSIS}

The analysis strategy for predicting the types of mineral commodities yet to be discovered in the Canadian Provinces and the URV of these commodities is as follows.

We first examine the hypothesis that the geologic information, as measured by the point counts, can be used to predict what kinds of mineral commodities are likely to be found. This is done in two steps.

(1) Comparison of groups of regions grouped upon the presence-absence of "time-petrographic" units versus groups of the same regions formed using the presence-absence of mineral commodities. The methodology for this comparison is based upon the assumption that the more similar the two groupings, the stronger the relationship between geology and type of commodities.

(2) Comparison of the number of "time-petrographic" units and the number of mineral commodities for a region. This is accomplished through a linear regression procedure. Next, the Canadian provinces are assigned among the groups of regions examined in other URV studies. These groups were initially formed using the presence-absence of "time-petrographic" units and without Canadian locations. Then steps (1) and (2) provide the rationale for predicting the type and number of commodities which are likely to be present in a province. Finally, for each province, a simulation procedure is used to estimate the URV for these yet undiscovered commodities. The analysis and results are covered in greater detail below. 
Analysis of the Relationship between Geology and Mineral Resources using Presence-Absence Data

The analysis was begun by examining whether or not the presence or absence of geologic units contains information about the commodity mix (i.e. the specific kinds [not amounts] of commodities). Using the states of the U.S. as a training set, two classifications were produced. First, the states were grouped using the "time-petrographic" presence-absence data (Menzie, 1977), This was followed by an independently performed classification of the states using mineral commodity presence-absence data. The classification based on commodity data yielded four groups while the classification based on "time-petrographic" data resulted in eight groups. The classifications along with proportion of the states falling within each class are given in Table 3. For example, Pennsylvania (PA) is in commodity class 2 , which contains $10 / 50$ or $20 \%$ of U.S. states, and "timepetrographic" class 5 , which contains $05 / 50$ or $10 \%$ of the states. A test of the independence of the two groupings using the contingency table techniques was deemed unsuitable because of the small number of observations vis-à-vis the number of cells in the analysis. However, another test statistic was derived under the assumption that the fewer the number of diagonal cells containing observations, or alternatively, the greater the number of off diagonal cells with no observations, the more similar are the classifications. A Monte Carlo simulation procedure was used to determine if the number of off diagonal empty cells is significantly greater in Table 3 than thar which might be obtained by a random distribution of 50 objects in an $8 \times 4$ array, the size of Table 3 . Such a table was simulated 500 times and the number of empty cells for each of these realizations was tallied in a frequency histogram, Figure 8. Table 3 has 21 observed cells containing no observations. Using Figure 8, the probability of getting 21 or more empty cells, if the classifications are independent, is $3 / 500$ or 0.006 . Using any conventional $\alpha$ level we must reject the hypothesis of independence between the two classifications. This affirms that contained in the geology, as measured here, is information about the kinds of commodities to be found at a given location.

A second investigation explored the relationship between the number of commodities and the number of "time-petrographic" units observed for a given location. This problem has an ana- 
Table 3. Classification of U.S. states ${ }^{+}$based on presence-absence of mineral commodities (columns) compared classification of U.S. states based on presence-absence of "time-petrographic" units (rows),

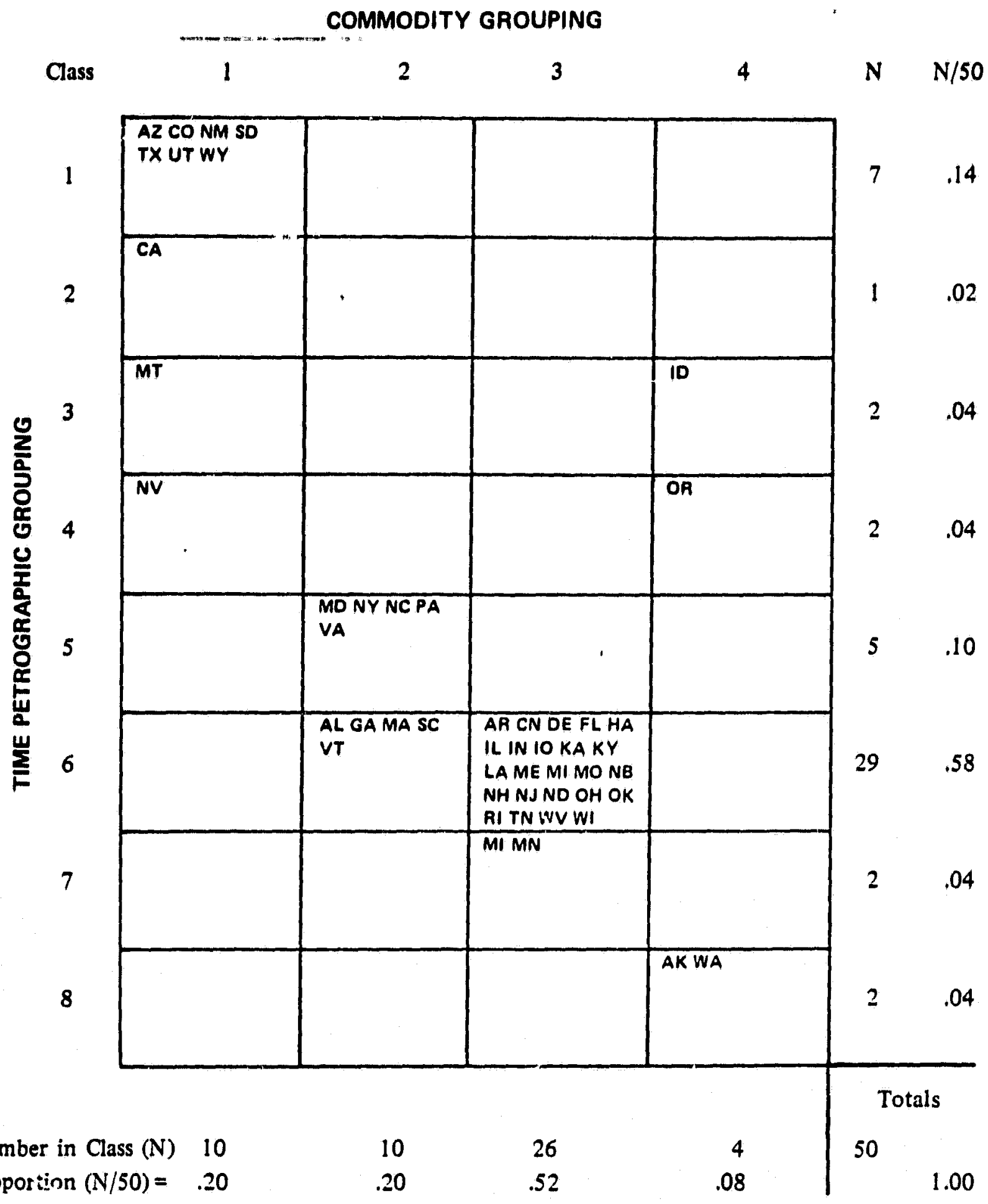

+STATE ARBREVIATIONS BASED ON U.S. POSTAL CODES 


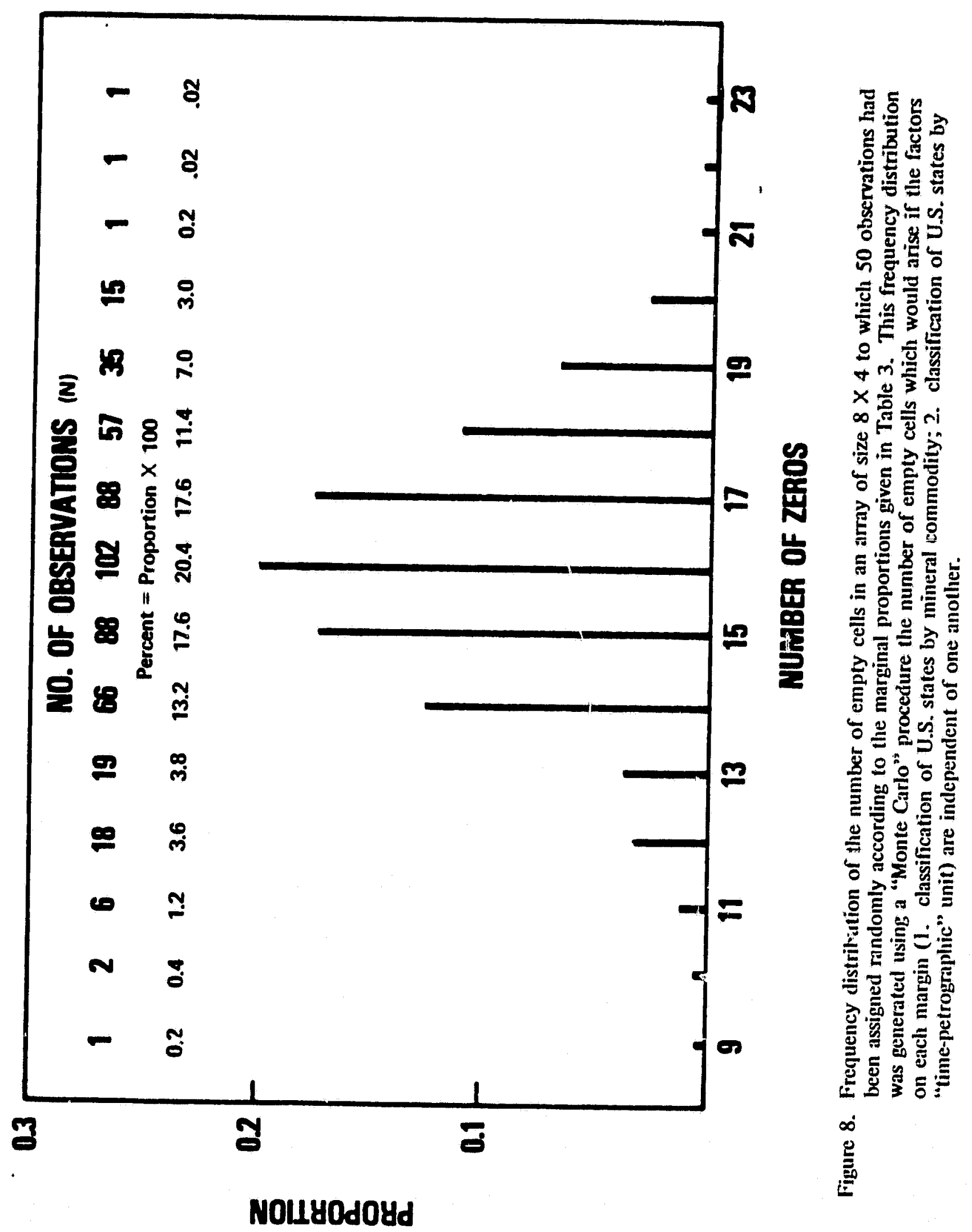


logue in the determination of species diversity for a population. Since we were interested in any and all mineral commodities, the measure of species diversity called richness wns used. ${ }^{6}$ Richness is the number of species (number of "time-petrographic" units or mineral commodities) minus one. Figure 9 is a plot of the relation of the richness of geologic units on the abscissn versus the richness of mineral commodities on the ordinate. The dashed line is a graph of the function $\mathrm{Y}=$ $11.277+1.846 \mathrm{X}$. This relationship was established by Griffiths et al. (1979) and is based upon analysis of locations which have previously undergone URV studies, these include the states of the U.S., Puerto Rico, South Africa, Zimbabwe, Australia, United Kingdom, Ireland, New Zealand, Mexico, Venezuela. As can be seen, with the exceptions of Ontario and British Columbia, the locations of Canada fall well below their expected mineral richness based upon their geologic endowment.

The estimates of the number of mineral commodities were refined by using information from geologically similar regions outside of Canada. To do this, the "time-petrographic" presenceabsence data was used to assign the Canadian locations to a previously developed classification ${ }^{7}$ composed of regions from other URV studies. Therefore, the locations in each group in Figure 10 are geologically similar.

For each group containing Canadian locations, the non-Canadian locations were used to estimate a linear model relating geologic richness and mineral resource richness. This model was used in turn to reestimate the expected number of mineral commodities for the Canadian location. Table 4 contains these refined estimates as well as $a \pm 2 \dot{\sigma}_{\mathrm{e}}$ range. Quebec and NWT formed their own group; there are no other locations in the training set with similar geology and hence the estimates, given in Table 4, for the number of commodities to be found at these two locations are based on the initial estimates using the linear regression given above. Initial estimates are

\footnotetext{
${ }^{6}$ The use of measures of species diversity for analyzing mineral resource endowment is more fully discussed in Griffiths et al. (1979, 1980).

${ }^{7}$ The classification was performed with the computer program CLUS (Rubin and Friedman, 1967) using the Rodgers and Tanimoto (1960) coefficient of association to create the similarity matrix.
} 


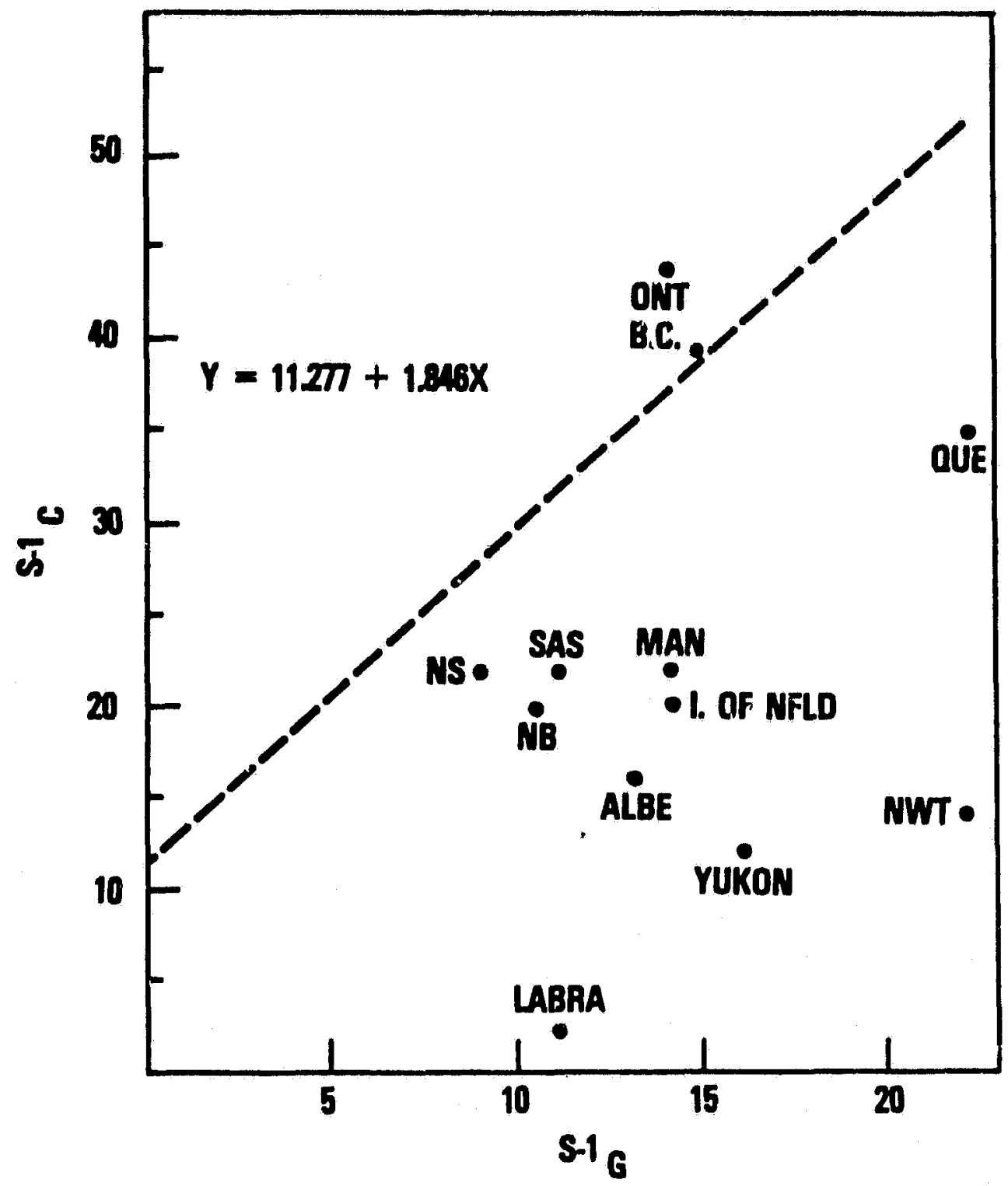

Figure 9. Scatter plot of richness of mineral resources $\left(S-1_{C}\right)$ and richness of "time-petrographic" units $\left(S-1_{G}\right)$ in Canadian provinces. Dashed line is due to Griffiths' et al., (1979) and represents this relationship for other locations which have undergone URV studies. 


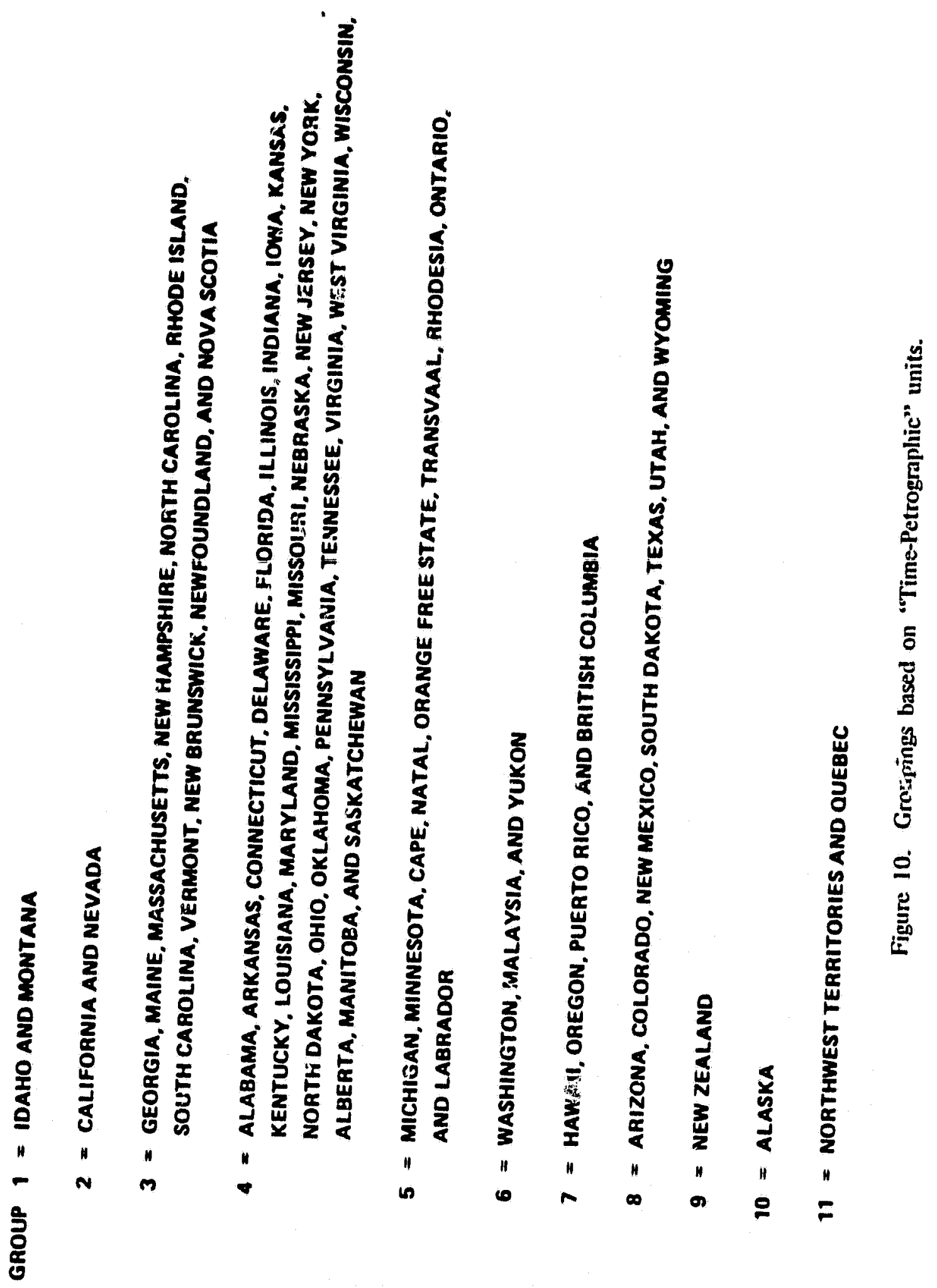




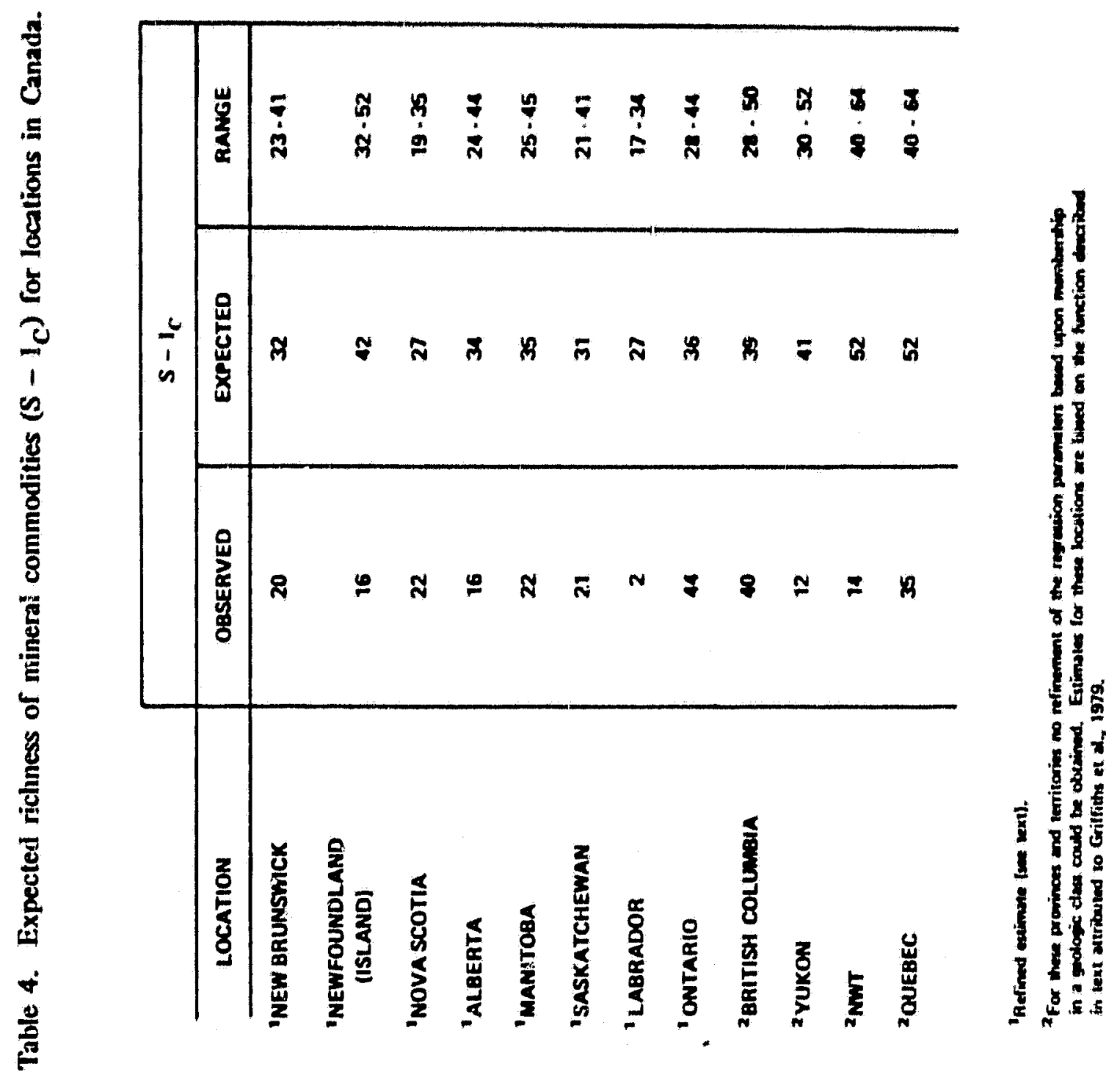


also given for British Columbla and the Yukon Territory, because there were an insurfieient number of non-Canadian location in their respectlve geologic groups to fit a linear model. British Columbia and Ontario have been dropped from further consideration as they lave already exceeded their expectations. However, most locations in Canada have not achleved even the lower bound on their expected number of commodities. Having estimated the number of com: modities to be found in locations in Canada, and having found that the locations are underproduced, the next question is what additional specific commodities can be expected.

\section{PREDICTING UNDISCOVERED MINERAL COMMODITIES AND THEIR URV}

For each Canadian location under study, a list was compiled of the (file 2) commoditles not discovered there but which are present in non-Canadian locations of the geologic group to which the study area belongs. The probability of occurrence of these commodities is then estimated as the number of locations possessing the commodity over the total number of nonCanadian lopations in the geologic group. Table 5 gives the potentially occurting mineral commodities and the probability of their occurrence in Manitoba. Based on these estimates of the probabilities of occurrence, the URV (1967 U.S, dollars per $\mathrm{km}^{2}$ ) of undiscovered mineral commodities were estimated. The estimated URV same from a frequency distribution created by repeatedly generating realizations using the following conditions;

(1) only those commodities with a probability of occurrence of .375 or better were used in the estimation procedures;

(2) a realization from a joint multivariate log normal distribution was created using estimates of the mean vector and variance - covariance matrix generated from the data;

(3) the values in the realization were exponentiated, summed, and logged (base 10),

Estimates of the mean and median of these distributions is given in Table 6. As can be seen, the Yukon, Newfoundland, Labrador, Saskatchewan and Manitoba are expected to produce more than 10,000 1967 U.S. dollars per $\mathrm{km}^{2}$ from mineral resources nor yet discovered, 


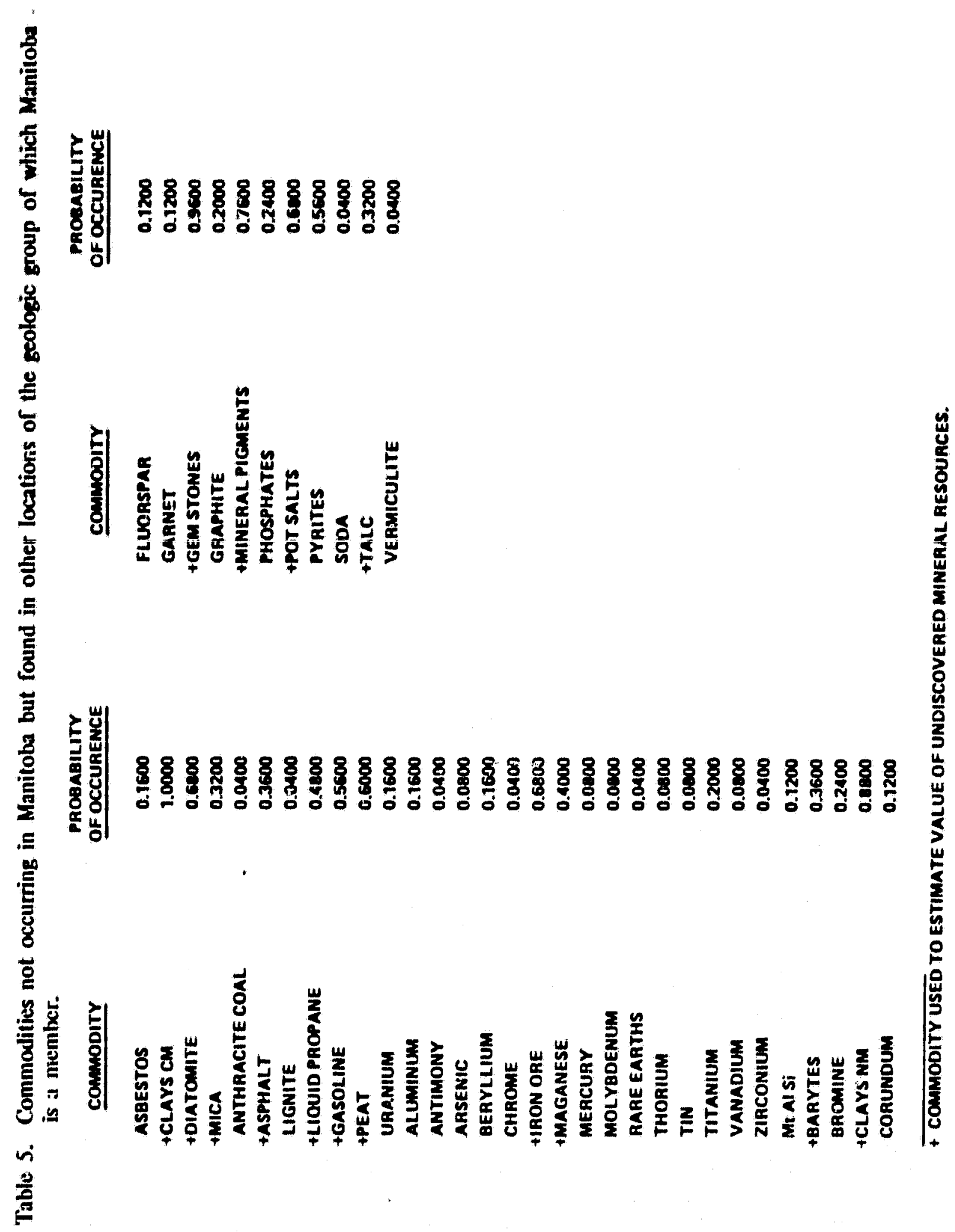


Table 6. Estimated URV (in U.S. 67 S) of undiscovered natural resources in selected Canadian locations.

\section{LOCATION}

ALBERTA

MANITOBA

NEW BRUNSWICK

NEWFOUNDLAND (I.)

LABRADOR

NWT

NOVA SCOTIA

SASKATCHEWAN

YUKON
10MEAN

$10^{\text {MEDIAN }}$

9,528

8,147

15,560

14,355

4,481

3,327

17,298

12,853

17,258

12,589

6,310

5,212

3,524

2,667

16,866

14,488

20,045

17,824

Alberta, for instance, will experience large increases in its URV from exploitation of fuels, however, those commodities were not included among the undiscovered commodities and so its URV does not reflect the value of the fuels. Quebec was used as the training set for estimating the URV of NWT, because Quebec was the only other geologically similar location among the locations used (see Figure 10) and clearly it is the better developed of the two locations. However, all indications are that Quebec itself is underdeveloped so the estimated URV for NWT is likely to be very conservative. Even sc, NWT would be worth an additional $\$ 2.132 \times 10^{10}$ (1967 dollars). ${ }^{8}$

\footnotetext{
${ }^{8}$ Arguments have arisen concerning the validity of any estimation of the mineral resource of a remote region like NWT. Such arguments point to the added costs of production in the region, the inaccessibility of the area and the inhospitable climate. These perceptions ignore many historical examples where such problems did not stop the exploitation of natural resources; examples include California in the mid 19th century, the deserts of the Middle East, the North. Slope of Alaska, the North Sea and, in the future, the MacKenzie Delta. Furthermore, as we look increasingly to the possibility of mining the moon and asteroids to meet resource needs, perception of the magnitude of the problems in exploitation of the NWT must ulso diminish.
} 
We believe that estimated URV's given in Table 6 are based on mineral commodities that will occur in exploitable quantities. This is because:

(1) occurrence in the training set was based on the commodity having been present in economic concentrations, and

(2) the commodity was included in the URV only if it occurred in 37.5 percent of the nonCanadian locations possessing geology similar to the Canadian location,

\section{CONCLUSIONS}

This research represents a case study using the unit regional value technique of mineral rresource evaluation. The procedure has been used to estimate the number, kinds and value of the mineral resources that will be discovered in the Canadian provinces and territories. Since the URV's and mineral production of other locations are used as a training set for the Canadian estimates, the Canadian estimates are likely to be conservative. This is because the URV estimates are based on the historical records of production of members of the training set and l) ne region is as yet completely exhausted of mineral resources, 2) technologies have changed economic concentration cutoffs. However, conservative resource estimates are not solely the province of URV estimates. Indeed, the use of single valued resource estimates has been consistently unsatisfactory. The URV estimates are meant to be viewed within a probabilistic framework and as an element of a set of estimates that incorporates the concept of uncertainty as a factor. Richard Sinding-Larsen (1981) has suggested that URV estimates represent a proportion of the upper half of the McKelvey Box, (McKelvey, 1973), that is the economically recoverable resources. The proportion of the total estimate represented by URV estimates, according to Sinding-Larsen, is the $(1-\hat{\mathrm{p}}) \cdot 100$ percentile where $\hat{p}$ is the probability estimated from the training set.

More generally, through the URV approach, we have created a reproducible, objective method for evaluation of a region's mineral resources. Operational definitions of geologic factors and mineral resources are stressed. In this way we have created a methodology for translating concepts 
and subjective observations into a form which is amenable to algebraic manipulation, Formal testing of subjective geologic hypotheses about the relationship between lithology and mineral resources is possible. Further, since geologists often disagree over interpretations, the translation procedure is such that any objective observation can be modified in turn to reflect the range of alternative opinions.

The system as illustrated here could be extended to allow the input of geologic expertise and information other than that presented. For example the probability of occurrence could be modified by expert opinion of other geologists. This approach presents the decision maker or explorationist with a global view of the potential for mineral resource exploration and developinent over large areas of Canada. There are several points in the analysis where inputs by a decision maker could be included. The outcome of the analysis would then be a test of the sensitivity of the procedure to the incorporated changes and in this way the explorationist could "game-out" the decision to explore areas.

\section{ACKNOWLEDGEMENTS}

This report is part of a research investigation (1974-1978) under the support of the U.S. Geological Survey (Grant No. 14-08-0001-6-141). The research for this report was cond ucted while the senior author was a research assistant at the Pennsylvania State University. 


\section{REFERENCES}

Ashby, W. R. 1971. An Introduction to Cybernetics. University Paperbacks, London, England. 295 pp.

Bartlett, M. S. 1954, A note on the multiplying of factors for various chi-squared approximations. Joumal of Royal Statistic Society, Series B, Vol. 16, p. 296-298.

Griffiths, J. C. 1967a. Mathematical exploration strategy and decisionmaking. Panel Dis, No. 5, 5th World Pet. Cong., Mexico. p. 599-604.

Griffiths, J. C. 1967b. Scientific Method in Analysis of Sediments. McGraw-Hill, New York, N.Y. 508 pp.

Griffiths, J. C. 1969. The Unit Regional Value Concept and Its Application to Kansas. Spec. Publ. State Geol. Surv. 28, Univ. of Kansas, Lawrence, Kansas. 48 pp.

Griffiths, J. C. 1972. Aspects of classification. In: R. Protz and I, P. Martini, Eds., Classification of Soils and Sedimentary Rocks. Proc. Symp. Center for Resources Development, University of Guelph. Guelph, Ontario, p. 123-146.

Griffiths, J. C. 1974. Petrology and Petrography of Detrital Sediments. Class notes from Min. 484, Spring. The Pennsylvania State University, University Park, Pa., 110 pp.

Griffiths, J. C. 1978. Mineral resource assessment using unit regional value concept. Journal of Mathematical Geology, Vol. 10, p. 441-472.

Griffiths, J. C. and D. A. Singer. 1971. Unit regional value of nonrenewable natural resource as a measure ot potential for development of large regions. Geological Socieły of Australia, Special Publication No. 3, p. 227-238. 
Griffiths, J. C. and W. D. Menzie. 1975. Variation in the value of mineral resourees; Part 1. The USA. Journal of Mathematical Geology, Vol. 7, p. 447-472.

Griffiths, J. C., M. L. Labovitz and D. A. Walsh. 1979. Measurements of geological diversity. IGCP Project 98 Symposium. Ictapa, Mexico.

Grifriths, J. C., A. T. Watson, and W. D. Menzie, 1980. Relationship between mineral resource and geological diversity. In: A. D. Miall, Ed. Facts and Principles of World Petroleum Occurrence. Canadian Society of Petroleum Geologists. Memoir 6.

Hurlbut, C. S. 1966. Dana's Manual of Mineralogy. John Wiley and Sons, Inc., New York, N.Y. $609 \mathrm{pp}$.

King, P. B. 1977. The Evolution of North America. Revised edition. Princeton University Press, Princeton, N.J. 197 pp.

Krynine, P. D. 1948. The megascopic study and field classification of sedimentary rocks. Journal of Geology, Vol. 56, p. 130-165.

Labovitz, M. L. 1976. Unit Regienal Value of the State of California. M. S. Thesis, the Pennsylvania State University, University Park, Pa. 348 pp.

Labovitz, M. L. 1978. Unit Regional Value of the Dominion of Canada. Ph.D. Thesis, the Pennsylvania State University, University Park, Pa. 366 pp.

l,abovitz, M. L., W. D. Menzie, and J. C. Griffiths. 1977, COMOD: A program for standardizing mineral-resource commodity data. Computers and Geosciences, Vol. 3, p. 497-537.

McKelvey, V. E. 1973. Mineral resource estimates and public policy. In: D. A. Brobst and W. P. Pratt, Eds., U.S. Mineral Resources, U.S. Geol. Survey Prof. Paper 820, p. 9-19. 
Missqn, H., B. R. Cooper, S. M. el Raba's, J, C. Griffiths and C. Sweetwood, 1978. Workshop on areal value estimation. Journal of Mathematical Geology, Vol. 10, p. 433-439.

Menzie, W. D. 1977. The Unit Regional Value of Republic of South Africa. Ph. D. thesis, the Pennsylvania State University, University Park, $\mathrm{Pa}, 235 \mathrm{pp}$.

Menzie, W. D., M. L. Labovitz, and J. C. Griffiths. 1977. Evaluation of mineral resources and the unit regional value concept. In: R. V. Ramani, Ed., Application of Computer Methods in the Mineral Industry, Soc. Mng. Eng, of Amer. Inst. Mng., Metall., and Petrol Eng. Inc., p. 322-329.

Rogers, D. J. and T. T. Tanimoto, 1960. A computer program for classirying plants. Science, Vol. 132, p. $1115-1118$.

Rubin, J. and H. P. Friedman. 1967. A Cluster Analysis and Taxonomy System for Grouping and Classifying Data. I.B.M. Corporation, Scientific Center, New York, N,Y, 221 pp.

Sinding-Larsen, R. 1981. Resource Assessment About Known and Unknown Ore and Coal Resources of Norway. Unpublişhed Report, Norwegian Department of the Environment.

Watson, A. T. 1977. An Appraisal of the Mineral Resources of New Zealand. M.S. thesis, the Pennsylvania State University, University Park, Pa. 126 pp.

\section{SOURCES OF MINERAL COMMODITY DATA}

Alberta Mines Division, Department of Mines and Minerals. Annual Report. Edmonton, Alberta.

British Columbia Minister of Mines and Petroleum Resources. Annual Report. Victoria, B.C.

Manitoba Department of Mines, Resources and Environmental Management. Annual Repdrt. Winnepeg, Manitoba. 
Mineral Development Sector, Energy Mines and Resources. 1976. Mineral Production of Canada by Province 1931-1975. Ottawa, 161 pp,

Mineral Development Sector, Energy Mines and Resources. Canadian Minerals Yearbook. Ottawa.

The Mineral Industry. McGraw-Hill Book Company, Inc., New York, N.Y.

Nova Scotia Department of Mines. Annual Report on Mines. Halifax, N.S.

Ontario Department of Mines and Northern Affairs. Annual Report. Toronto, Ontario.

Quebec Department of Natural Resources. Mining Industry in Quebec. Quebec, Canada.

Statistics Canada. 1957. Canadian Mineral Statistics 1886-1956 and Mining Events 1604-1956. Reference Paper no. 68. Ottawa.

SOURCES OF GEOLOGICAL POINT COUNT DATA

Alberta

Greene, R. and F. L. Copeland. 1972. Geological Map of Alberta. Scale 1:1,267,200. Map 35. Research Council of Alberta, Edmonton, Alberta.

\section{British Columbia}

Jackson, E. V. 1976. Generalized Geological Map of the Canadian Cordillera. Scale 1:250,000.

\section{Manitoba}

Bostock, H. H., L. M. Cumming, B. S. Norford, A. W. Norris, L. L. Price, and B. V. Sanford. 1967. Geology of Hudson Bay Lowlands. Scale 1:1,000,000. Map 17-1967, in Paper 67-60. Geological Survey of Canada, Ottawa. 
Currie, K, L. 1960. Whiskey Jack Lake, Manitoba. Scale 1:253,440. Map 30-1960. Geological Survey of Canada, Ottawa.

Davison, W. L. 1962. Tadoule Lake, Manitoba. Scale 1:253,440. Map 30-1962. Geological Survey of Canada, Ottawa.

Davison, W. L. 1963. Munroe Lake, Manitoba. Scale 1:253,440. Map 35-1963. Geological Survey of Canada, Ottawa.

Davison, W. L. and W. W. Heywood. 1964. Caribou River, Manitoba, Scale 1:253,440. Map 17-1965, in Paper 65-25. Geolugical Survey of Canada, Ottawa.

Davison, W. L. and W. W. Heywood. 1967. Nejanilini Lake, Manitoba. Scale 1:253,440. Map 14-1967. Geological Survey of Canada, Ottawa.

Geological Division, Mines Branch. 1964. Geological Map of Manitoba. Scale 1:1,267,200. Map 65-1. Department of Mines and Natural Resources, Winnepeg, Manitoba.

New Brunswick

Potter, R. R., E. V. Jackson, and J. L. Davies. 1968. Geological Map of New Brunswick. Scale 1:500,000. Department of Natural Resources, Saint John, New Brunswick.

Newfoundland Island of Newfoundland

Williams, H. 1967. Geology of the Island of Newfoundland. Scale 1:1,000,000, Map 1231A. Geological Survey of Canada, Ottawa.

Labradcir

Greene, B. A. 1971. Geological Map of Labrador. Scale 1:1,000,000. Mineral Resources Division, Department of Mines, Agriculture and Resources, Province of Newfoundland and Labrador. St. Johns, Newfoundland. 
$N W T$ :

Douglas, R. J. W. 1968b. Geological Map of Canada. Scale 1:5,000,000, Map 1250A. Geological Survey of Canada, Ottawa.

\section{Nova Scotia}

Wright, J, D. 1965. Geological Map of Nova Scotai. Scale 1:506,380. Department of Mines, Halifax, Nova Scotia.

\section{Ontario}

Ayres, L. D., S. B. Lumbers, V. G. Milne, and D. W. Robeson. 1970. Ontario Geological Map. Scale 1:1,013,760. Maps 2995-3000. Ontario Department of Mines and Northern Affairs, Toronto, Ontario.

\section{Quebec}

Laurin, A. F. 1969. Geological Map of Quebec. Scale 1:1,013,760. Department of Natural Resources, Mines Branch. Quebec, Canada.

\section{Saskatchewan}

Witaker, S. H. and D, E. Pearson. 1972. Geological Map of Saskatchewan. Scale 1:1,267,200. Province of Saskatchewan Department of Mineral Resources and Saskatchewan Research Council. Regina, Saskatchewan.

\section{Yukon}

Geology and Mineral Deposits of Yukon Territory and part of Southwest District of Mackenzie, Northwest Territories. 1972. Scale 1:1,500,000. Open file 87. Geological Survey of Canada, Ottawa. 


\section{FIGURE CAPTIONS}

Figure 1. Comparison of observed frequency histogram of $\log _{10}$ URV (in 1967 U.S. dollars/ $\mathrm{km}^{2}$ ) of the U.S. states with the expected normal distribution possessing the same mean and variance. The statistics of $\sqrt{ } b_{1}, b_{2}$ and $X_{12}^{2}$ are used in tests of the skewness, kurtosis and goodness of fit, respectively. NS means that the statistic is not significantly different from the value for a normal distribution.

Figure 2. Comparison of total production of mineral resources in U.S. states and Canadian provinces. The mean, XBAR, and standard deviation are estimated from the U.S. states.

Figure 3. The data cube exhibiting the three dimensions of characteristics, time and regions.

Figure 4. Generalized cybernetic input-output model of mineral resource development.

Figure 5. "Time-Petrographic" classification (from Menzie, 1977; modinied by Watson, 1977).

Figure 6. Relationship between subdivisions of Canadian Precambrian and "time-petrographic" classification (after King 1977 and Labovitz, 1978).

Figure 7. Input-Output model of Figure 4 displaying relationships between varieties of timepetrographic inputs and mineral resource outputs.

Figure 8. Frequency distribution of the number of empty ceils in an array of size $8 \times 4$ to which 50 observations had been assigned randomly according to the marginal proportions given in Table 3. This frequency distribution was generated using a "Monte Carlo" procedure the number of empty cells whicl: would arise if the factors on each margin (1. classification of U.S. states by mineral commodity; 2. classification of U.S. states by "time-petrographic" unit) are independent of one another. 
Figure 9. Scatter plot of richness of mineral resources $\left(S-I_{C}\right)$ and richness of "timepetrographic" units $\left(S-I_{G}\right)$ in Canadian provinces. Dashed line is due to Griffiths et al. (1979) and represents this relationship for other locations which have unciergone URV studies.

Figure 10. Groupings based on "Time-Petrographic" units. 


\section{TABLES}

Table 1. Standard set of mineral resource commodities which enables the comparison of mineral resources from different locations. Each of these commodities, which are collectlyely known as Filo 2, has an operational definition (given in Labovitz et al., 1977) which allows local commodity names to be assigned to the standarcl set.

Table 2. Number of points counted and their area of influence for the provinces of Canada.

Table 3, Classification of U.S. states ${ }^{+}$based on prosence-absence of mineral commodities (columns) compared classification of U.S. states based on presence-absence of "timepetrographic" units (rows).

Table 4. Expected richness of mineral commodities $\left(S-l_{C}\right)$ for locations in Canada.

Table 5. Commodities not occurring in Manitoba but found in other locations of the geologic group of which Manitoba is a member.

Table 6. Estimated URV (in U.S. 67 S) of undiscovered natural resources in selected Canadian locations. 